\title{
Learning Style Preferences of College Student
}

\author{
Arda Purnama Putra \\ Elementary School Teacher Education \\ State University of Malang \\ Malang, Indonesia \\ arda.purnama.fip@um.ac.id
}

\author{
Sutansi \\ Elementary School Teacher Education \\ State University of Malang \\ Malang, Indonesia \\ sutansi.fip@um.ac.id
}

\author{
Achmad Badawi \\ Graduate School \\ State University of Malang \\ Malang, Indonesia \\ badawi.pgsd@gmail.com
}

\begin{abstract}
Research on preferential learning styles has long been carried out since 1981. Several studies reveal that learning styles can affect one's learning outcomes. However, there are several studies which reveal that learning styles do not affect one's learning outcomes. This difference is interesting to discuss more deeply. This article will discuss the various types of college student learning styles and the results of previous studies on the influence of learning styles on student learning outcomes. This article also discusses the types of learning styles according to some experts. There are three types of learning styles, namely auditor, visual, and kinesthetic. While the others define 4 kinds of learning styles, namely Activists, Reflective, Theoretical, and Pragmatic.
\end{abstract}

Keywords- learning style, college student, learning outcomes.

\section{INTRODUCTION}

Each student has a different way of learning. Different learning methods for each student will affect the knowledge gained. The different ways of learning can be caused by internal factors and external factors. Research into the trend of learning styles has long been carried out since 1981 . There has even been a measurement model of learning style preferences. One method for identifying trends in learning styles, namely the measurement model of Kolb's Learning Style Inventory or Kolb's LSI [1] and the Myers Briggs Type Indicators or MBTI model [1].

Some studies reveal that learning styles can influence learning outcomes obtained by individuals. Several other studies stated that there was no influence between learning styles and individual learning outcomes. Students with certain types of learning styles show better performance because they are satisfied during the lecture [2] [3]. Other results revealed that students with learning styles similar to their lecturers, tend to have better performance compared to other students who have learning styles that are not similar to lecturers [4]. While in the study Prastiti \& Pujiningsih revealed the opposite. There is no influence of learning style preferences on student learning outcomes in UM accounting majors [5].

This thing supports research which reveals that the tendency of learning styles in each department is different. This is reinforced by the research of Van Adel which compares the learning style trends of accounting students with management students and business students found that students of accounting study programs tend to have different learning styles than students of management study programs and business students [6]. Johnson \& Miller explain that student learning style is determined by the characteristics of the field of science taken [7]. Students who study in physical, mathematical and chemical disciplines are more likely to have a visual learning style.

Each student has a unique personality that is different from other students. Each student is different in the level of performance, learning speed, and learning style. This different way of learning shows the easiest way for students to absorb information during learning. The easiest and fastest way to learn languages as learning styles [8]. Lecturers in teaching must pay attention to student learning styles. This is because in each teaching the effectiveness will depend on the way or style of learning of students, in addition to their personal and intellectual abilities. The lecturers' lack of understanding of student learning styles has a detrimental effect on students. This will result in student learning achievement not in accordance with the level of student intelligence capabilities. Therefore, the lecturer must know and know the learning style of each student so that it can facilitate the learning process

\section{DISCUSSION}

\section{A. Learning Style Preferences}

Learning styles are attitudes and behaviors that determine individual preferences in learning [9]. Learning styles as styles of thinking, ways of remembering, ways of observing, ways of solving problems when individuals are in the learning process [10]. In learning in college, the appropriate learning style of students will determine the success of students in learning in college [11] [12]. Sukadi revealed that learning styles are a combination of the way a person absorbs knowledge and how to organize and process information or knowledge gained [13]. Meanwhile, according to Nasution, learning style is a consistent way that is carried out by a student in capturing stimulus or information, how to remember, think, and solve problems [14].

Learning styles between one individual and another individual are different, this difference allows the individual to have a difference in the lifestyle and personality [15]. Students with different learning styles have different behaviors in receiving, interacting, and responding to learning in an environment [16]. Learning styles are very important to know so that teachers can adjust to children's learning styles. Felder \& Spurlin revealed that the differences in learning styles of each student are important to be known to teachers because information about learning styles can help teachers become more sensitive to students, especially in delivering class material [10]. There are many learning styles that have been discovered by researchers. Every individual has a different learning style. There is no 
superior learning style, there is a learning style that is appropriate to the context, task, and personality [17].

\section{B. Learning Style According to De Porter and Hernacki}

De Porter and Hernacki identify three learning styles that a person uses in learning [18]. The three learning styles are explained as follows.

\section{1) Visual}

Visual learning style is a learning style by seeing, seeing, and observing. The dominant senses are used in visual learning styles, namely the eye. This learning style is owned by individuals who like to follow illustrations, read instructions, observe pictures, review events directly, and so on. A visual type, will quickly learn materials presented in writing, charts, graphs, pictures. Anyway, it's easy to learn the lesson material that can be seen with the visualization tool. On the contrary, it is difficult to learn when confronted with materials in the form of sound, or movement [19].

The characteristics of visual learning styles are: (a) Tending to see the attitude, movement, and lips of the teacher who is teaching; (b) not a good listener when communicating; (c) when you get instructions to do something, usually you will see other friends and then act yourself; (d) do not like to talk in front of the group and do not like listening to others. look passive in discussion activities; (e) less able to remember information given orally; (f) prefer demonstration rather than verbal explanation; (g) can sit quietly in a crowded and crowded situation without being disturbed; (h) speak rather quickly; (i) concerning appearance in dress / presentation; (j) not easily disturbed by noise; $(\mathrm{k})$ remembering what is seen, rather than what is heard; (l) prefer to read than read; (m) the reader is fast and diligent; (n) often knowing what to say, but not good at choosing words; (o) prefer to do demonstrations rather than speeches; (p) prefer music than art; (q) having problems remembering verbal instructions unless they are written, and often asking people to repeat them.

\section{2) Auditory}

The auditory learning style is a learning style by listening. This learning style is more dominant using the sense of hearing. Children who are auditorial type, easy to learn materials presented in the form of sound (lecture), as soon as the teacher explains he quickly catches the material of the lesson, besides that the word from friend (discussion) or radio voice/cassette he easily catches it. Someone who has a learning style auditors will feel difficulties in the lessons presented in the form of writing, touching, movement movements.

The characteristics of visual learning styles are: (a) able to remember well the teacher's explanation in front of the class, or the material discussed in the group/class; (b) great listeners: children easily master advertising/song material on television/radio; (c) tend to talk a lot; (d) do not like to read and generally are not good readers because they are unable to remember well what they have just read; (e) lack of skill in working on writing/writing tasks; (f) nice to discuss and communicate with others; ( $g$ ) less interested in paying attention to new things in the surrounding environment, such as the presence of new children, the presence of a notice board in the corner of the classroom; (h) when working like talking to yourself; (i) neat appearance; (j) easily disturbed by noise; (k) learning by listening and remembering what is discussed rather than being seen; (l) happy reading aloud and listening; (n) move their lips and say the writing in the book when reading; (o) better spelling hard than writing it; $(p)$ prefer oral jokes rather than reading comics; (q) having problems with work involving visual; (r) speak in a patterned rhythm; (s) can repeat and mimic the tone, rhythm, and color of the sound.

\section{3) Kinesthetic}

Kinesthetic learning style is a learning style by moving, working, and touching. A person with this learning style is easier to catch lessons when he moves, feels, or takes action. Individuals of this type, easy to learn the material in the form of writings, movements, and difficult to learn the material in the form of sound or vision. In addition, learning is kinesthetically related to practice or learning experience directly. The characteristics of the kinesthetic learning style are: (a) touching everything that is met, including when learning; (b) difficulty staying silent or sitting sweet, always wanting to move; (c) doing everything that allows his hands to be active; (d) likes to use real objects as learning aids; (e) difficult to master abstract things like maps, symbols, and udders; (f) liked practice/experiment; (g) love games and physical activity; (h) speak slowly; (i) neat appearance; (j) not too easily disturbed by the commotion situation; (k) Learning through manipulation

\section{Learning Style According to Honey \& Mumford}

Honey \& Mumford identify four learning styles that a person uses in learning [20] [21]. The four learning styles are explained as follows.

\section{1) Activists}

This learning style is owned by individuals who learn by doing. They like to involve themselves in new experiences and will always try others. They are more interested in doing first and then thinking about the consequences. This learning style is good in terms of (a) leading a group; (b) working with others in problem-solving, games, and roleplaying; (c) engage in new experiences, problems, and opportunities. This learning style is not good in terms of (a) listening to lectures or reading texts; (b) writing and thinking; (c) analyzing and interpreting a lot of data; (d) follow regular instructions.

\section{2) Reflector}

Individuals who have this learning style learn by observing and thinking about what happened. They like to consider all possibilities from various points of view before they give opinions. They spend more time listening and observing. They tend to be wiser and more careful. This learning style is good in terms of (a) performing tasks without a tight grace period; (b) given time to think and investigate before commenting or acting; (c) given the opportunity to review what has happened. This learning style is not good in terms of (a) being forced to lead in groups; (b) do something without preparation; (c) work with tight deadlines. 


\section{3) Theoretical}

Individuals who have this learning style prefer to understand the theory of each incident. They need models, concepts, and facts to learn. They like to analyze and synthesize a situation. They will feel uncomfortable with subjective judgments. This learning style will be effective when: (a) in a restructuring situation and with a clear purpose; (b) activities that are supported by ideas and concepts that form a model, system, or theory; (c) is needed to understand complex situations. This learning style is less effective in (a) situations that emphasize emotions and feelings; (b) if the activity is not restructured or ambiguous; (c) when asked to act without knowing the principle or concept first.

\section{4) Pragmatic}

Individuals who have a pragmatic learning style always want to try everything. They are looking for new ideas that can be applied to each problem. They like a lot of things. They tend to be impatient with open discussion. They are practitioners. This learning style will be effective when: (a) there is a clear relationship between current topics and needs; (b) they are shown techniques with clear practical advantages; (c) they can try various things with feedback from an expert; (d) they can copy samples, or copy a model. This learning style is less effective when: (a) there are no practical benefits; (b) there is no clear guide on how to do it; (c) dealing with many theories.

Honey \& Mumford argue that most people tend to only have one or two learning styles learning [20] [21]. Different learning may be more appropriate to certain learning styles. By knowing the dominant learning style will help in measuring how much an activity will affect a person.

\section{Results of Previous Studies}

Certain learning styles show better learning outcomes because they are satisfied during the lecture [2]. Marriott expressed the same thing, learning styles can influence student learning outcomes [11]. Other results revealed that students with learning styles that were similar to their lecturers, tended to have better learning outcomes compared to other students who had learning styles that were not similar to lecturers [4]. Papilaya, J \& Huliselan research revealed the same thing. Learning style is the key to students' success in learning [22] [23] [24] [25] [26]. Learning style has a contribution or influence of $52 \%$ on students' learning achievement and the remaining $48 \%$ is influenced by other variables [27]. While in the study Pujiningsih revealed the opposite. There is no influence of learning style preferences on student learning outcomes in UM accounting majors [5]. Nurhasanah's research revealed that there was no influence between visual, auditory, kinesthetic learning styles together on mathematics learning achievement [28]. Other studies also revealed that learning styles did not affect in biology learning achievement [29].

\section{RESULTS}

Learning style is thinking attitude and behavior, how to remember, how to observe, how to solve problems when individuals are in the learning process. Learning styles are very important to know so that teachers can adjust to children's learning styles. There are many learning styles that have been discovered by researchers. Every individual has a different learning style. There is no learning style that is superior, there is a learning style that is appropriate to the context, task, and personality. There are three types of learning styles, namely auditor, visual, and kinesthetic. While the others define 4 kinds of learning styles, namely Activists, Reflective, Theoretical, and Pragmatic.

There are differences in the results of research on the influence of learning styles on student learning outcomes. This is due to differences in subject and object of research. However, research reveals about the influence of learning styles on learning outcomes more than others. Apart from the results of the study, it is very important for teachers to know their students' learning styles so that the learning provided by the teacher can be absorbed to the maximum.

\section{CONCLUSION AND SUGGESTION}

\section{A. Conclusion}

Based on the discussion above, a conclusion can be drawn that there are many types of student learning styles when viewed from various sides. When viewed from the side of sensory receptors, there are three types of learning styles, namely auditor, visual, and kinesthetic. In terms of the way students study, there are 4 types of learning styles, namely Activist, Reflector, Theoretical, and Pragmatic.

\section{B. Suggestion}

Based on the discussion described above, further research should be conducted on differences in student learning styles in each department. Experimental research on the influence of learning styles on learning outcomes also needs to be done in each department so that the cause of the research gap can be known.

\section{REFERENCES}

[1] Kolb. D.A. Learning Style Inventory Self Scoring Inventory and Interpretation Buuklt. Boston, NA: MCBER and Company. 1985

[2] Baker, K.B., Greenwald, R.A., Walker, A.D.M., Bythrow, P.F., Zanetti, L.J., Potemra, T.A., Hardy, D.A., Rich, F.J. and Rino, C.L. (1986). A case study of plasma processes in the dayside cleft. Journal of Geophysical Research 91. doi: 10.1029/JA091iA03p03130. issn: 0148-0227.

[3] Grasha \& Grasha. Teaching with Style. Pittsburgh, PA: Alliance Publishers. 1996

[4] Geiger and Boyle. Learning styles of students and instructors: An analysis of course performance and satisfaction. The Accounting Educators' Journal 4:86-101.1992

[5] Pujiningsih, S. Kecenderungan Gaya Belajar Mahasiswa Akuntansi FE-UM, Penelitian DIPA, Lemlit UM. 2007

[6] Van Adel BA, Kostic C, Deglon N, Ball AK, Arsenijevic Y. Delivery of ciliary neurotrophic factor via lentiviral-mediated transfer protects axotomized rentinal ganglion cells for na extended periode of Time. Hum Gene Ther. 14:103-115. 2003

[7] Johnson, A., \& Miller, J. Comparison of student's learning style in STEM discipline. Proceedings of the Industrial Engineering Research Conference. 2010.

[8] Hamzah, B. U. Orientasi baru dalam psikologi siswa yang memiliki gaya belajar. Jakarta: Bumi Aksara. 2010.

[9] Honey, P. \& Mumford, A. Learning Style Helper Guide. Peterhoney Publication Limited. 2006. 
[10] Felder, R.M. \& Spurlin, J.E. Application, reliability, and validity of the index of learning styles. Intl. J. Engr. Education, 21(1), 103-112. 2005.

[11] Marriott, N. \& Marriott, P. Student Learning Style Preferences and Undergraduate Academic Performance at Two UK Universities. International Journal of Management Education 3(1): 4-13. 2003.

[12] Sangster, A. Objective Tests, Learning to Learn and Learning Styles. Journal Accounting Education 5(1): 131-46. 1996

[13] Sukadi.. Progressive learning: Learning by spirit. Bandung: MQS. 2008.

[14] Nasution, S. Berbagai pendekatan dalam proses belajar mengajar. Bandung: Bumi Aksara. 2008

[15] Zhang, L-F. \& Sternberg, R.J. A therefold model of intellectualstyles. Educational Psycology Review, 17(1), 2. 2005.

[16] Junko. Learning styles and error correction: How do learning styles affect students' perceptions toward error correction in a foreign language classroom? (online). Available: http://www.eric.ed.gov/ERICDocs/data/ericdocs2sq1/content_storage _01/0000019b/80/17/86/35.pdf (August 28, 2018)

[17] Rosewell, J. (2005). Learning styles. 1st ed. [ebook] The Open university, p.5. Available at http://www.open.edu/openlearnworks/pluginfile.php/69355/mod_pag e/content/1/learning_styles.pdf [Accessed 2 Sept. 2018].

[18] De Porter dan Hernacki. Quantum Learning. Bandung: Kaifa. 2002.

[19] Abu Ahmadi dan Widodo Supriyono. Psikologi Belajar. Jakarta: Rineka. Cipta. 2008.

[20] Honey, P. and Mumford, A. The Manual of Learning Styles, Peter Honey Associates. 1986a.
[21] Honey, P. and Mumford, A. Learning Styles Questionnaire, Peter Honey Publications Ltd. 1986b.

[22] Papilaya, J \& Huliselan N. 2016. Identifikasi Gaya Belajar Mahasiswa Jurnal Psikologi Undip Vol.15 No.1 April 2016, 5663Sudijono, Anas. 2008. Pengantar Statistik Pendidikan. Jakarta : rajawali Pres.

[23] Hussain, Nasreen \& Ayub, Nadia. Learning Styles of Students and Teaching Styles of Teachers in Business Education: A Case Study of Pakistan. Procedia - Social and Behavioral Sciences 69 ( 2012 ) 1737 $-1740.2012$.

[24] Khandaghi, Maghsood Amin \& Farasat, Maryam. The effect of teacher's teaching style on students' adjustment. Procedia Social and Behavioral Sciences 15 (2011) 1391-1394

[25] Bota, Oana Alina \& Tulbure, Cristina. Aspects Regarding the Relationship Between Teaching Styles and School Results. Procedia Social and Behavioral Sciences 203 ( 2015 ) 285 - 290

[26] Shaari, Abdull Sukor et al. The Relationship Between Lecturers' Teaching Style And Students' Academic Engagement. Procedia Social and Behavioral Sciences 118 ( 2014 ) 10 - 20

[27] Ibnu R. Khoeron, Nana Sumarna, Tatang Permana. Pengaruh Gaya Belajar Terhadap Prestasi Belajar Peserta Didik Pada Mata Pelajaran Produktif. Journal of Mechanical Engineering Education, Vol.1, No.2. 2014.

[28] Nurhasanah. Pengaruh Gaya Belajar Terhadap Prestasi Belajar Matematika Siswa Kelas VII SMP Yapis Manokwari. Prosiding Seminar Nasional Volume 02, Nomor 1. 2016.

[29] Yen Chania, M. Haviz, Dewi Sasmita. Hubungan Gaya Belajar Dengan Hasil Belajar Siswa Pada Pembelajaran Biologi Kelas X SMAN 2 Sungai Tarab Kabupaten Tanah Datar. 2016. 